University of Michigan Law School

University of Michigan Law School Scholarship Repository

Articles

Faculty Scholarship

1910

\title{
Liability of Water Companies for Losses by Fire in Actions of Tort
}

\author{
Ralph W. Aigler \\ University of Michigan Law School
}

Available at: https://repository.law.umich.edu/articles/1605

Follow this and additional works at: https://repository.law.umich.edu/articles

Part of the Business Organizations Law Commons, Energy and Utilities Law Commons, and the Torts Commons

\section{Recommended Citation}

Aigler, Ralph W. "Liability of Water Companies for Losses by Fire in Actions of Tort." Mich. L. Rev. 8 (1910): 485-6.

This Response or Comment is brought to you for free and open access by the Faculty Scholarship at University of Michigan Law School Scholarship Repository. It has been accepted for inclusion in Articles by an authorized administrator of University of Michigan Law School Scholarship Repository. For more information, please contact mlaw.repository@umich.edu. 
Liability of Water Companies for Iosses by Fire in ACrrons of ToRT.In Fisher v. Greensboro Water Supply Company, I28 N. C. 375, it was held that the defendant water company was liable in damages in an action of tort for negligent failure to furnish sufficient water pressure in the mains of the city, by reason of which negligence the plaintiff's house was burned. The only duty on the part of the defendant to furnish water grew out of a contract made by the company with the city and the fact that the defendant had entered upon the business of supplying water pursuant to such contract. In disposing of the case the supreme court said: "We think the plaintiff was entitled to judgment as prayed for. There was an express and legal obligation upon the part of the defendant to provide and furnish ample protection against fires, and a breach of that obligation and a consequential damage to the plaintiff. Although action may have been maintained upon a promise implied by law, yet an action founded in tort was the more proper form of action and the plaintiff so declared." Some time after the rendition of the judgment in this case a proceeding was instituted in the United States court for the foreclosure of a certain mortgage upon the property of the defendant above, which mortgage was prior in time to the lien of the above judgment. Under a statute of the state making judgments for torts prior liens upon the property and earnings of incorporated companies over mortgages which were prior in point of time, the judgment creditor under the judgment above referred to intervened claiming the benefit of the statute. The court held that the intervener was entitled to the preference claimed. On appeal the decision was affirmed by the circuit court of appeals and on certiorari the supreme court affirmed the ruling. Guardian Trust and Deposit Co. v. Fisher, 200 U. S. 57. It will be seen that the right of the judgment creditor to the preference was based upon the fact that his judgment was rendered in a tort action, and whether the ruling of the court below that the judgment was such was the question considered by the supreme court. Mr. Justice BREWER, in delivering the opinion of the court, said: "We shall assume, without deciding, that the nature of the causes of action upon which the state judgments were rendered is open for consideration in the Federal court in the foreclosure proceeding. The statute subordinates the mortgage to judgments for torts. Now what is the judgment? $* * *$ From the conclusion thus reached (This follows the extract from the opinion of the North Carolina court above quoted) we are not inclined to dissent," etc. Apparently then in answer to the argument that the judgment under consideration could not have been rendered upon a tort liability because there was no tort involved, the learned justice examines the question on its merits and concludes that the acceptance of the contract with the city and the entering upon the business imposed upon the water company a public duty to furnish water for public and private purposes and for fire protection, and a negligent failure to perform the duty was actionable in tort by the party aggrieved. In Mugge v. Tampa Waterworks Co., 52 Fla. 37I, 42 South. 8I, 6 L. R. A. (N. S.) II7I, I20 Am. St. Rep. 207, this question was presented to the supreme court of Florida, the conclusions of Mr. Justice BREWER in the Fisher case being approved and followed.

In a very recent decision, however, by the circuit court of appeals for the 
fifth circuit, the doctrine of a tort liability under facts essentially the same as -involved in the Fisher and Mugge cases was examined and denied. German Alliance Insurance Co. v. Home Water Supply Co. (Nov. 1909), 174 Fed. 764. The court considers the Fisher case and concludes that the observations of Mr. Justice BREWER were unnecessary to the decision of the matter then before the court, the only point in issue being the nature of the judgment of the North Carolina court, which being found to have been based on the tort any examination into the merits of the case presented to the state court was beyond the point and the conclusions of the court thereon dicta. On the matter of the water company being engaged in a "public calling" the court, after an examination of the authorities, concludes that it was not. The opinion of the court is not convincing, and it is to be hoped that the supreme court may consent to bring the case up on certiorari thus settling authoritatively, at least so far as the federal courts are concerned, this important and interesting question. For a further discussion of the matter see 5 Mich. L. REv. 362.

R. W. A. 